\title{
Erwinia carotovora subsp. carotovora and Erwinia-Derived Elicitors HrpN and PehA Trigger Distinct but Interacting Defense Responses and Cell Death in Arabidopsis
}

\author{
Tarja Kariola, ${ }^{1}$ Tiina A. Palomäki, ${ }^{1}$ Günter Brader, ${ }^{1,2}$ and E. Tapio Palva ${ }^{1,2}$ \\ 'Department of Biosciences, Division of Genetics, P.O. Box 56, FIN-00014 University of Helsinki, Finland; ${ }^{2}$ Institute \\ of Biotechnology, P.O.Box 56, FIN-00014 University of Helsinki, Finland
}

Submitted 11 July 2002. Accepted 6 November 2002.

\begin{abstract}
We have used an $h r p$-positive strain of the soft rot pathogen Erwinia carotovora subsp. carotovora to elucidate plant responses to this bacterial necrotroph. Purified virulence determinants, harpin ( $\mathrm{HrpN})$ and polygalacturonase (PehA), were used as tools to facilitate this analysis. We show that HrpN elicits lesion formation in Arabidopsis and tobacco and triggers systemic resistance in Arabidopsis. Establishment of resistance is accompanied by the expression of salicylic acid (SA)-dependent, but also jasmonate/ethylene (JA/ET)-dependent, marker genes PRI and PDF1.2, respectively, suggesting that both SA-dependent and JA/ETdependent defense pathways are activated. Use of pathwayspecific mutants and transgenic NahG plants show that both pathways are required for the induction of resistance. Arabidopsis plants treated simultaneously with both elictors PehA, known to trigger only JA/ET-dependent defense signaling, and HrpN react with accelerated and enhanced induction of the marker genes $P R I$ and PDF1.2 both locally and systemically. This mutual amplification of defense gene expression involves both SA-dependent and JA/ETdependent defense signaling. The two elicitors produced by E. carotovora subsp. carotovora also cooperate in triggering increased production of superoxide and lesion formation.
\end{abstract}

Additional keywords: induced resistance, programmed cell death, signal pathway.

Plants are normally resistant to a variety of potential pathogens due to both preformed and induced resistance mechanisms. These induced defense responses are activated upon recognition of a pathogen, pathogen-derived elicitor molecules, or elicitors released from the plant by the action of pathogens. Consequently, plant resistance can be triggered either by a specific recognition event between an avirulence ( $a v r)$ gene product of a pathogen and a corresponding resistance $(R)$ gene product of a host plant, as in a gene-for-gene type of resistance (Flor 1971; Keen 1990) or between unspecific elicitor molecules and plant receptors (Nürnberger 1999). Recognition of a pathogen or an elicitor is often associated with localized necrosis known as the hypersensitive response (HR). HR is charac-

Corresponding author: E. T. Palva: Telephone: +358-9-19159600; Fax: +358-9-19159079; E-mail: tapio.palva@helsinki.fi.

T. Kariola and T. A. Palomäki contributed equally to this study. terized by rapid cell death and tissue necrosis at the site of pathogen attack, resulting in restriction of pathogen growth and spreading and, thus, resistance. Such recognition events will then activate defense signaling in the surrounding tissues, leading to enhanced disease resistance also in the uninfected parts of the plant (Dangl et al. 1996; Goodman and Novacky 1994).

Recent work has demonstrated the presence of distinct signal pathways leading to activation of different sets of defense genes in plants (Glazebrook 1999; Reymond and Farmer 1998; Thomma et al. 2001a). The best-characterized of these induced defense responses is the systemic acquired resistance (SAR), triggered by e.g. necrotizing pathogens. SAR results in a longlasting resistance in the uninfected parts of the plant against a further challenge by a broad range of pathogens (Ryals et al. 1996; Sticher et al. 1997) and is characterized by the expression of certain pathogenesis related $(P R)$ genes, such as $P R 1$ (Uknes et al. 1992; Ward et al. 1991), also in distant parts of the plant. SAR induction is dependent on the accumulation of SA and requires the activity of the positive regulator NPR1 (Cao et al. 1994; Delaney et al. 1995). Several jasmonate (JA) and ethylene (ET) dependent resistance mechanisms that are independent of SA have also been documented (Thomma et al. 1998; 2001a). JA has been implicated as a signal molecule in wound response against feeding insects (Doares et al. 1995) as well as in resistance against the bacterial pathogen Erwinia carotovora (Brader et al. 2001; Norman-Setterblad et al. 2000). Both JA and ET signaling are required for resistance against fungal pathogens like Alternaria brassicicola and Botrytis cinerea, but also against $E$. carotovora, which has been shown to activate this defense pathway, leading to enhanced systemic resistance (Thomma et al. 1998; 2001a; Norman-Setterblad et al. 2000). Root-colonizing, plant growth-promoting rhizobacteria trigger induced systemic resistance (ISR) (van Loon et al. 1998). ISR is independent of SA and dependent on JA and ET and also on NPR1, the key regulator of SAR signaling (Pieterse et al. 1998; Pieterse and van Loon 1999).

Accumulating evidence argues for a crosstalk between the signal pathways (Thomma et al. 2001a). JA and ET act synergistically in inducing genes for several PR proteins, including osmotin (Xu et al. 1994), defensin (Penninckx et al. 1998), and HEL (Norman-Setterblad et al. 2000). ET has also been shown to enhance SA-mediated signaling (Lawton et al. 1994), and $\mathrm{SA}$ has been shown to enhance JA-dependent responses ( $\mathrm{Xu}$ et al. 1994). On the other hand, SA and its functional analogs have also been reported to prevent the expression of JA-dependent defense genes (Gupta et al. 2000; Peña-Cortés et al. 
1993; Penninckx et al. 1996; Vidal et al. 1997), and similarly, JA has been shown to interfere with SA-dependent signaling (Niki et al. 1998). Another line of evidence indicating crosstalk between the different signal pathways comes from the studies

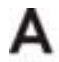

$\mathrm{kDa}$ 1 2 3
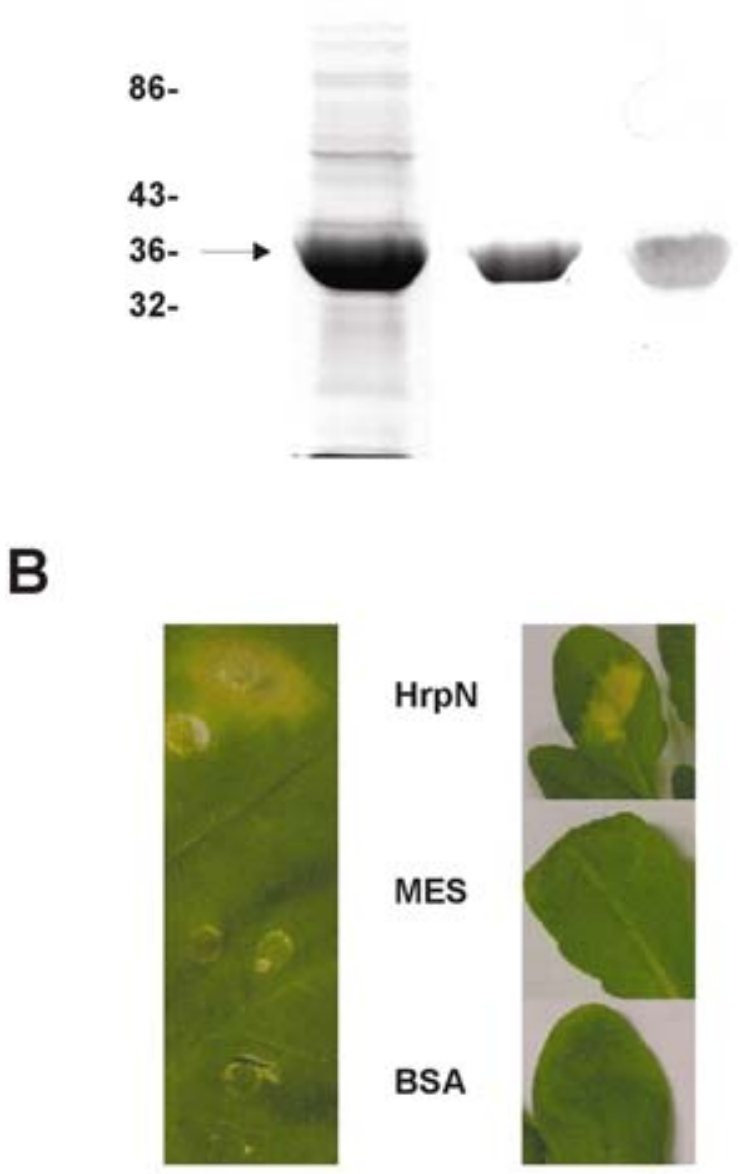

HrpN
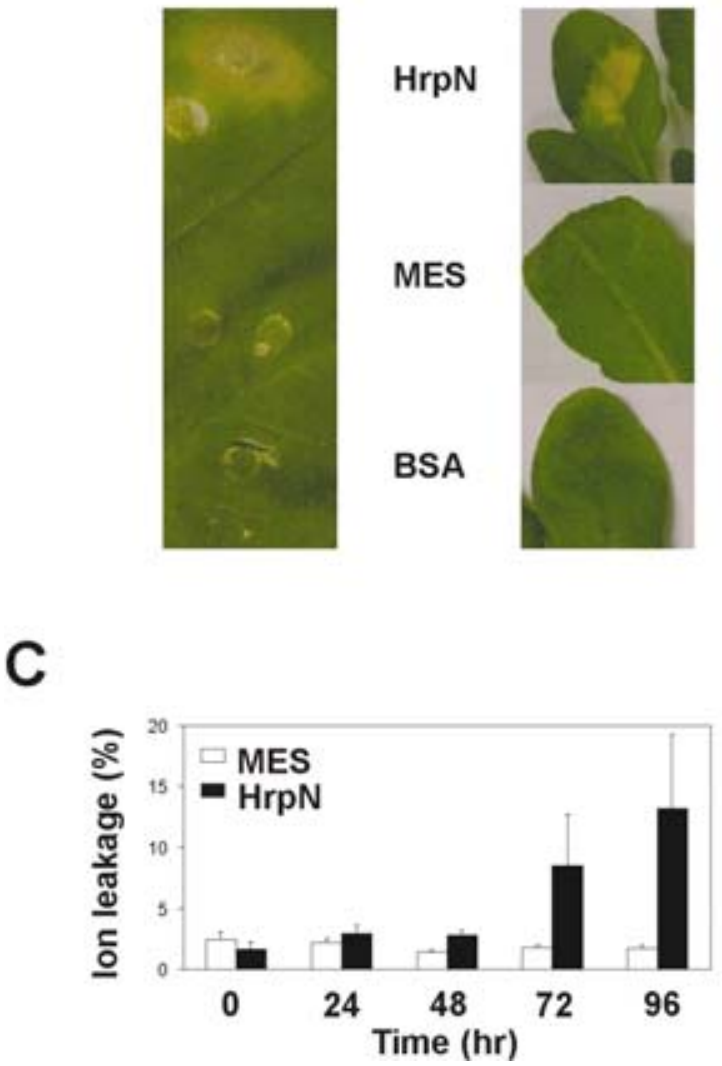

Fig. 1. Purified HrpN induces a hypersensitive response-like response in Arabidopsis and tobacco. A, Overexpression, purification, and Western blot detection of Erwinia carotovora subsp. carotovora HrpN protein from Escherichia coli strain M15. Lane 1, crude extract of M15 carrying pTPE101; lane 2, purified HrpN; lane 3, Western blot of purified HrpN using antihistidine antibody. The arrow indicates the overproduced 36kDa HrpN. B, Tobacco (left) and Arabidopsis (right) leaves four days after infiltration with $\mathrm{HrpN}(300 \mu \mathrm{g} / \mathrm{ml}), 5 \mathrm{mM}$ MES buffer ( $\mathrm{pH} 6.5)$, or acetylated bovine serum albumin (BSA; $1,500 \mu \mathrm{g} / \mathrm{ml}$ ). C, Arabidopsis leaves were infiltrated with $5 \mathrm{mM}$ MES or $\mathrm{HrpN}(300 \mu \mathrm{g} / \mathrm{ml})$, and cell death was measured as relative ion leakage (percentage of total ions \pm standard error) at the indicated time points after treatment. of MAP kinases. Recently, it was shown that MAP kinase 4 (MPK 4) has a role in crosstalk between SA- and JA-dependent signal pathways (Petersen et al. 2000); while repressing SAR response, MPK4 is required for expression of JA-responsive defense genes.

The plant defenses can be induced by the action of different elicitors, for example, proteins secreted by pathogens or the compounds of the plant cell wall released by the action of microbial enzymes (Nürnberger 1999; Boller 1995). The elicitors involved may also act simultaneously, resulting in amplified, synergistic effect on the induction of plant defense, and the effect of this simultaneous action can even be greater than the sum of the individual effects of the elicitors (Boller 1995).

We use the gram-negative phytopathogen E. carotovora subsp. carotovora as a model to probe for plant defense responses and to understand the signal processes involved in the plant-pathogen interaction. E. carotovora subsp. carotovora is a broad host range, soft rot necrotroph that uses an array of plant cell wall-degrading enzymes (PCWDE), including pectinases, cellulases, and proteases, as primary virulence factors (Kotoujansky 1987; Pérombelon and Kelman 1980). Besides macerating plant tissue during disease progression, these extracellular enzymes also trigger a signal transduction cascade leading to plant defense response and resistance (NormanSetterblad et al. 2000; Palva et al. 1993; Vidal et al. 1997, 1998). The defense response elicited by PCWDE is independent of SA and appears to be primarily dependent on JA/ET signaling in both tobacco (Vidal et al. 1997, 1998) and Arabidopsis (Norman-Setterblad et al. 2000). Some strains of E. carotovora have also been shown to possess hrp (hypersensitive response and pathogenicity) genes (Mukherjee et al. 1997; Rantakari et al. 2001) that contribute to virulence. Similar to other Hrppositive bacterial pathogens the hrp cluster of E. carotovora subsp. carotovora encodes proteins required for type III secretion and delivery of bacterial effector proteins to the plant cells (Rantakari et al. 2001). Harpins are acidic, glycine-rich, heatstable proteinaceous elicitors of HR in various plant-pathogen interactions (He et al. 1993; Wei et al. 1992) and are also secreted through this system. Some harpins have also been shown to function as elicitors of induced resistance (Bauer et al. 1997; Huang et al. 1988; Wei et al. 1992; Wei and Beer 1996). The harpin of E. amylovora was recently shown to induce the SAR response in Arabidopsis (Dong et al. 1999). However, the role of harpin in sensitive hosts is less clear.

We have characterized the responses of Arabidopsis triggered by two types of defense elicitors, harpin HrpN and a PCWDE, polygalacturonase PehA. We used transgenic NahG plants and various signal transduction mutants to dissect the signal pathways triggered, and we demonstrated that E. carotovora subsp. carotovora and $\mathrm{HrpN}$ induce both SA-dependent and JA/ET-dependent signal pathways in Arabidopsis. Moreover, HrpN was shown to induce resistance against Erwinia, and this induced resistance response required both SA-dependent and JA/ET-dependent signaling pathways. Furthermore, we show that both the induction of plant defense genes and the lesion formation were strongly enhanced by the cooperative action of the two types of elicitors.

\section{RESULTS}

Purified HrpN of E. carotovora subsp. carotovora SCC1 elicits lesion formation and induces disease resistance.

To characterize the E. carotovora subsp. carotovora harpin and to elucidate its biological activity, the $h r p N$ gene was first isolated from a genomic lambda library of the strain SCC1 (Rantakari et al. 2001), subcloned to an expression vector and sequenced. Comparison of the deduced amino acid sequence of 
HrpN from SCC1 demonstrated clear structural similarity with harpins previously described from E. carotovora Ecc71 (Mukherjee et al. 1997), E. chrysanthemi (Bauer et al. 1995), E. amylovora (Wei et al. 1992) and, most recently, from Pantoea stewartii (Frederick et al. 2001). HrpN is $99 \%$ identical to the harpin of Ecc71 and shares approximately $48 \%$ identity with the harpins of E. amylovora and E. chrysanthemi. This structural similarity, including the presence of glycine-rich regions and the lack of cysteine, indicates that $\mathrm{HrpN}$ from SCC1 is a typical harpin.

To study the biological activity of E. carotovora subsp. carotovora harpin, we purified the $N$-terminally $\mathrm{His}_{6}$-tagged $\mathrm{HrpN}$ protein produced in Escherichia coli. The purity of the eluted and dialyzed HrpN was estimated by sodium dodecyl sulfatepolyacrylamide gel electrophoresis (SDS-PAGE), and its identity was confirmed immunologically using anti-His-Tag antibody (Fig. 1A). The biological activity of the protein was tested both in Arabidopsis and tobacco, in which the infiltration of $300 \mu \mathrm{g} \mathrm{ml}^{-1}$ of purified $\mathrm{HrpN}$ caused visible symptoms within 48 to $72 \mathrm{~h}$ (Fig. 1B), but no lesion formation was seen when plants were treated with the controls, MES buffer and acetylated bovine serum albumin. The symptoms caused by HrpN treatment were accompanied by increased ion leakage three to four days after infiltration (Fig. 1C).

To determine the capability of HrpN to induce resistance in Arabidopsis against E. carotovora subsp. carotovora, wildtype Col-0 plants were locally treated with the purified HrpN protein. After this pretreatment $(24 \mathrm{~h})$, we challenged the plants with E. carotovora subsp. carotovora $\mathrm{SCC} 1$ inoculated into systemic leaves. As shown in Figure 2A, the HrpN-pretreated plants were significantly less macerated after $24 \mathrm{~h}$ than the MES-pretreated control plants. To quantify the effect of HrpN, we measured bacterial growth in both $\mathrm{HrpN}$-treated and control plants (Fig. 2B). The results show a clear reduction of bacterial growth in HrpN-pretreated plants. After an initial multiplication, the bacterial growth was stopped in these plants, while it continued in MES-treated controls. In conclusion, HrpN treatment appears to induce plant defense and establishes resistance against E. carotovora subsp. carotovora.

\section{HrpN and E. carotovora subsp. carotovora SCC1} induce both $\mathrm{SA}$-dependent and

JA/ET-dependent defense pathways.

To elucidate the identity of one or more HrpN-triggered defense pathways in Arabidopsis, we employed the pathwayspecific marker genes $P R 1$, responsive to SA, and $P D F 1.2$, responsive to JA and ET. HrpN-induced expression of these genes was compared to that induced by the pathogen itself and to another Erwinia-derived defense elicitor polygalacturonase (PehA) that is known to induce the JA/ET-dependent defense pathways (Norman-Setterblad et al. 2000; Vidal et al. 1998). Arabidopsis Col-0 plants were locally inoculated with $E$. carotovora subsp. carotovora SCC1 bacteria $\left(10^{6} \mathrm{CFU} /\right.$ plant $)$ or infiltrated with preparations of HrpN or PehA, and the accumulation of PRI and PDF1.2 transcripts was followed up to five days by Northern analysis (Fig. 3). The purified HrpN triggered a strong local induction of $P R I$ but a relatively weak systemic response. Surprisingly, the expression of PDF1.2 was also induced within 24 to $48 \mathrm{~h}$. In accordance with previous results, PehA triggered only a weak and delayed induction of PRl but a strong and rapid expression of PDF1.2. Plants inoculated with $\mathrm{SCC} 1$ reacted locally with strong expression of both $P R 1$ as well as $P D F 1.2$. All treatments induced $P D F 1.2$ also in systemic leaves whereas the systemic expression of PRI was fairly weak. These results show that both HrpN and SCC1 are capable of triggering not only SA-dependent but also JA/ET-dependent defense genes.
Both SA and JA signaling are required for establishing HrpN triggered resistance to E. carotovora subsp. carotovora.

To elucidate the importance of different signaling pathways in $\mathrm{HrpN}$-induced resistance, we challenged Arabidopsis signal pathway mutants and transgenic plants with SCC1 bacteria. Transgenic NahG plants unable to accumulate SA were employed to characterize the need of the SA-dependent SAR pathway and JA-insensitive coil and jarl mutants were employed to elucidate the role of pathways involving JA signaling. HrpN treatment did not induce resistance to challenge inoculation by SCC1 in NahG plants but, instead, enhanced bacterial growth when compared with control plants (Fig. 4). In the JA-insensitive coil plants, HrpN was not capable of inducing resistance either, but HrpN-treated and control plants supported bacterial growth to a similar extent. Similar results were obtained in another type of JA-signaling mutant, jarl. Finally, we measured the bacterial growth in NahG coil plants in which both pathways were blocked. These plants showed the most severe symptoms and supported vigorous bacterial growth in HrpN-treated as well as in control plants, and the treatment with $\mathrm{HrpN}$ did not lead to any enhanced resistance. In coil as well as in NahG coil plants, infection was so severe

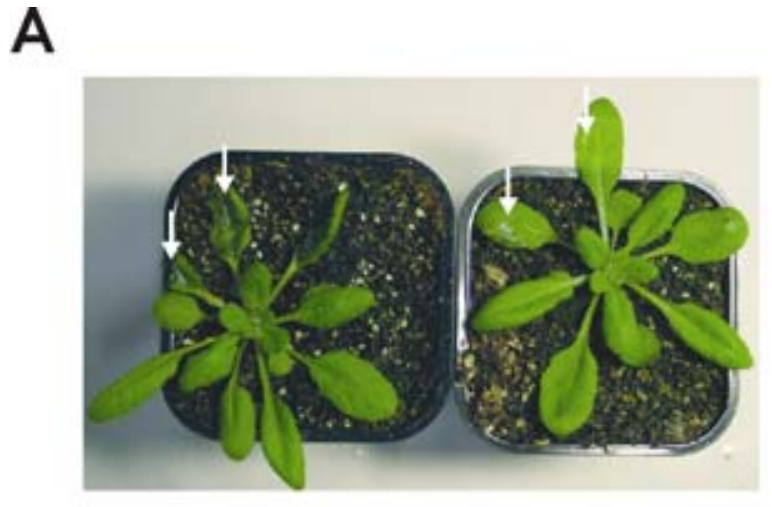

MES pretreated HrpN pretreated

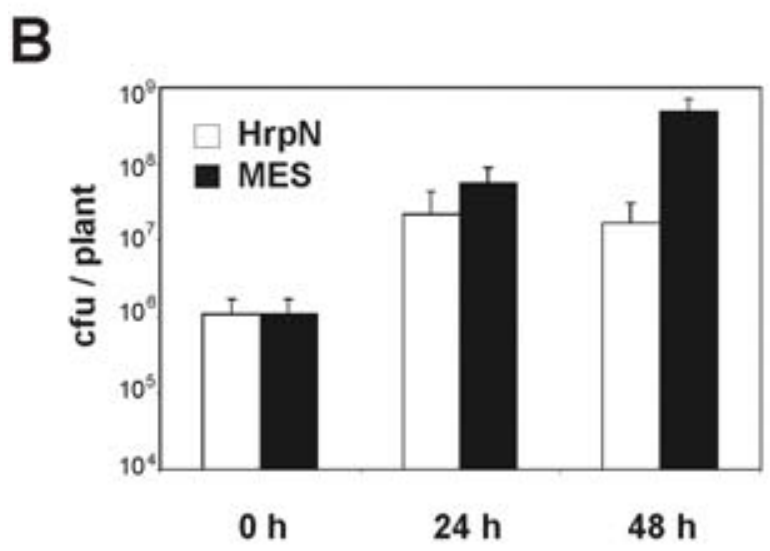

Fig. 2. HrpN induces resistance in Arabidopsis. Two leaves of Arabidopsis Col-0 plant were inoculated by infiltration with Erwinia carotovora subsp. carotovora SCC1 (indicated by white arrows) $24 \mathrm{~h}$ after pretreatment of two opposite leaves with $\mathrm{HrpN}(300 \mu \mathrm{g} / \mathrm{ml})$ or $5 \mathrm{mM}$ MES. A, Visual differences in HrpN and MES pretreated Col-0 plants $24 \mathrm{~h}$ after infection with $E$. carotovora subsp. carotovora $\mathrm{SCC} 1\left(5 \times 10^{6} \mathrm{CFU} / \mathrm{ml}\right)$. B, Growth of E. carotovora subsp. carotovora SCC1 in Col-0 after pretreatment with HrpN (white bars) or MES (black bars). The plant samples were collected into $0.9 \% \mathrm{NaCl}$ at 0,24 , and $48 \mathrm{~h}$ after inoculation $(9.2 \times$ $10^{5} \mathrm{CFU} /$ plant). Bacterial growth was measured from five to seven parallel samples by plating serial dilutions on L-Amp $\left(50 \mu \mathrm{g} \mathrm{ml}^{-1}\right)$ plates and is indicated as CFU/plant \pm standard error. 
that most of the plants were totally macerated within 48 to 72 h. Taken together, these results suggest that HrpN-induced resistance to E. carotovora subsp. carotovora $\mathrm{SCC} 1$ requires both SA- and JA-dependent defense signaling.

\section{HrpN and PehA elicitors cooperate}

in the induction of plant defense gene expression.

Production of both elicitors HrpN and PehA by E. carotovora subsp. carotovora SCC1 and the enhanced expression of defense genes by bacterial inoculation compared with either HrpN or PehA alone (Fig. 3) led us to assess the effect of simultaneous treatment with both elicitors on wild-type Arabidopsis. Northern hybridization analysis (Fig. 5A and B) showed that both PDF1.2 and PRI were induced both faster and more strongly by the combination of HrpN and PehA than by either of the elicitors alone. Even more remarkable was the enhanced systemic induction of both SA- and JA/ET-dependent marker genes, especially the strong systemic induction of $P R 1$, hardly detectable with any of the single treatments (Fig. 5B). Even the systemic induction of PDF1.2 was enhanced.

To study the role of the SA-dependent and SA-independent defense pathways in this enhanced plant response, we used transgenic NahG plants as well as several signal transduction mutants of Arabidopsis. When the JA/ET pathway was blocked, the expression of PDF1.2 was reduced or even abolished, as seen in HrpN/PehA-treated, ET-insensitive ein2-1, JA-insensitive coil and jarl, as well as in JA-deficient triplefad mutants (Fig. 5C). The induction of SA-dependent PRI, however, was still somewhat stronger in JA/ET-pathway mutants after the double treatment when compared with that after treatment with HrpN alone (data not shown). As expected, PRI induction was abolished in transgenic NahG plants as well as in $n p r 1$ mutant plants. The induction of PDF1.2 resembled that seen in wild-type plants after treatment with PehA alone. In NahG coil plants, in which both pathways are blocked, the induction of both PDF1.2 and PRI was abolished almost completely. Glutathione S-transferase GST1 accumulates in response to oxidative stress (Conklin and Last 1995). Local GST1 induction after HrpN/PehA treatment was similar to wild-type plants in all the mutants and in transgenic NahG and
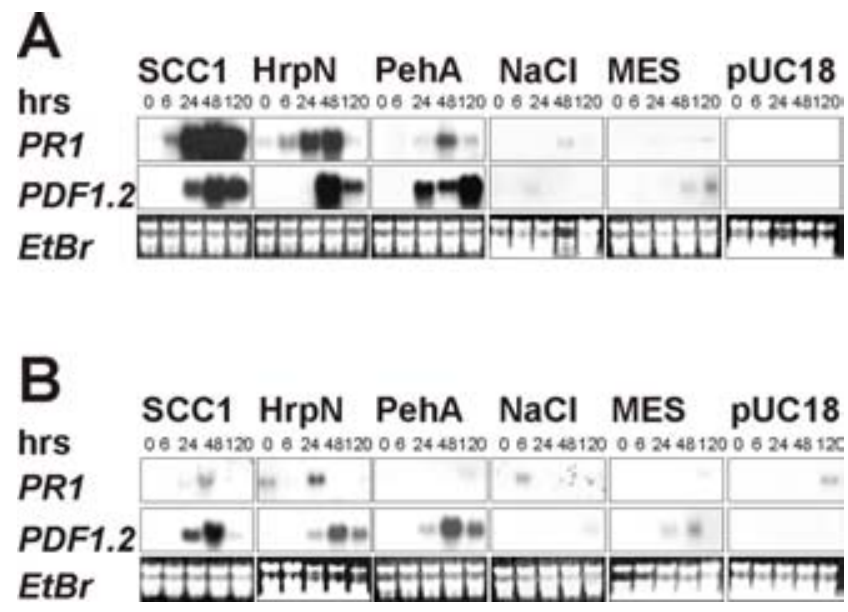

Fig. 3. Erwinia carotovora subsp. carotovora SCC1 and elicitors HrpN and PehA induce both local and systemic expression of defense genes in Arabidopsis. Arabidopsis Col-0 plants were treated with E. carotovora subsp. carotovora suspension $\left(3.7 \times 10^{6} \mathrm{CFU} / \mathrm{ml}\right)$, HrpN $(300 \mu \mathrm{g} / \mathrm{ml})$, PehA (6.2 units $/ \mathrm{ml})$, or with controls $0.9 \% \mathrm{NaCl}, 5 \mathrm{mM}$ MES buffer, or PehA $^{-}$vector control (pUC18). A, Local (treated) and B, systemic (untreated) leaf samples were collected $0,6,24,48$, and $120 \mathrm{~h}$ after the treatment. Total RNA was extracted and analyzed by Northern hybridization with gene-specific probes for PRI and PDF1.2. As a control for equal loading, ethidium bromide staining of RNA is shown at the bottom. seemed to be independent of the pathways affected. However, a slight reduction in GSTI induction was seen in coil (Fig. 5C). In conclusion, HrpN and PehA synergistically induce a more rapid and strong defense response in Arabidopsis.

\section{Synergistic action of HrpN and PehA trigger enhanced lesion formation and superoxide production.}

The reactive oxygen species (ROS) are known to play a role in the formation of HR, a form of programmed cell death (PCD) associated with the induction of plant defense responses (Greenberg 1997). The enhanced plant response to simultaneous HrpN and PehA treatment compared with treatment with either elicitor alone prompted us to characterize lesion formation and superoxide production in these plants. As shown in Figure 6A HrpN/PehA-treated leaves showed enhanced and accelerated lesion formation as compared with treatments with single elicitors. Already, 6-h treatment resulted in the formation of clear and massive HR-like lesions. Nitroblue tetrazolium (NBT) staining was used to visualize superoxide formation in the treated leaves (Fig. 6B). The staining showed that superoxide was formed within $2 \mathrm{~h}$ after $\mathrm{HrpN} / \mathrm{PehA}$ treatment and could not be detected at that time after treatment with either elicitor alone. The specificity of the staining in detecting superoxides was confirmed by adding superoxide dismutase (SOD) along with NBT (Fig. 6B). The extent of tissue collapse and cell death of these double-treated leaves was quantified by measuring ion leakage (Fig. 6C). Compared with plants treated with either HrpN or PehA alone, a clearly synergistic effect was seen when these elicitors were used simultaneously. There was a massive increase in ion leakage, and the reaction itself was also much more rapid (Fig. 6C). In conclusion, superoxide production and lesion formation were strongly enhanced by the synergistic action of the Erwinia elicitors HrpN and PehA.

\section{DISCUSSION}

Some harpins have been shown to elicit disease resistance (Bauer et al. 1997; Huang et al. 1988; Wei et al. 1992; Wei and Beer 1996), but only recently has the focus been moved toward understanding the signaling mechanisms underlying this defense response. For example, the harpin of E. amylovora was shown to activate disease resistance in Arabidopsis through SA- and NPR1-dependent signal pathways (Dong et al. 1999). In this paper, we describe purification of the harpin isolated from a necrotrophic phytopathogen E. carotovora subsp. carotovora, the response reaction it elicits in Arabidopsis, and present evidence on the involvement of distinct interacting signal pathways in this response.

Harpins as elicitors of HR are generally established, but their role in pathogenesis is somewhat controversial. The first isolated harpin $\mathrm{HrpN}_{\mathrm{Ea}}$ from E. amylovora was shown to be required for disease production in a susceptible host but not for HR induction in a resistant host (Wei et al. 1992). However, the role of $\mathrm{HrpN}_{\mathrm{Ea}}$ appears to vary depending on the E. amylovora strain and the host plant, since different reactions have been observed in different situations (Barny 1995). The role of harpins in necrotrophic bacteria, such as E. chrysanthemi and E. carotovora is also somewhat obscure. An $h r p N_{\text {Ech }}$ mutant was unable to elicit HR and was less virulent than the wild type (Bauer et al. 1995), whereas an $h r p N_{\text {Ecc }}$ mutant was fully pathogenic but unable to cause HR (Cui et al. 1996). The role of harpin in pathogenicity of E. carotovora is particularly difficult to assess due to the massive production of PCWDEs and maceration of plant tissue, which can mask a potential HR response. To avoid these difficulties, we used purified HrpN protein from E. carotovora subsp. carotovora to study its biological activity on Arabidopsis and tobacco and showed that it 
was a potent inducer of defense related genes and lesion formation as well as enhanced resistance.

The use of purified HrpN and pathway-specific marker genes allowed us to elucidate the signal pathways involved in plant response to HrpN. Similar to results with E. amylovora harpin, the HrpN of E. carotovora subsp. carotovora was shown to induce the SAR-specific PRI marker gene, whose induction is dependent on SA accumulation. However, the results also show that E. carotovora subsp. carotovora $\mathrm{HrpN}$ additionally triggers another defense response pathway, as evidenced by induction of the JA/ET-dependent PDF1.2 gene expression by the purified, his-tagged harpin. The transient but strong induction of the PDF1.2 gene by HrpN is not likely to be caused by any impurity in the HrpN preparation, since there are no other visible proteins in Coomassie-stained SDS-PAGE gels, apart from HrpN. Furthermore, the MES buffer control itself did not cause necrotic lesions in plants or the induction of defense related genes, apart from some weak wound response. Moreover, the systemic induction of PDF1.2 by $\mathrm{HrpN}$ is quite strong, comparable to that induced by either SCC1 bacteria or PehA treatment. Interestingly, HrpN-induced accumulation of PDF1.2 mRNA seems to be faster in systemic than in local tissues, indicating that more than one signal is formed, one acting locally and another systemically. Evidence supporting the role for a harpin in activating several distinct signal transduction cascades has been recently presented. A harpin of Pseudomonas syringae pv. syringae has been suggested to activate multiple signaling pathways, one leading to ROS production and another to the activation of two MAP kinases, AtMPK4 and AtMPK6, via distinct pathways (Desikan et al. 2001). AtMPK6 is, in turn, activated by $\mathrm{H}_{2} \mathrm{O}_{2}$ suggesting a role for the harpin in amplifying the ROS production.

The purified HrpN was shown to induce systemic resistance in Arabidopsis wild-type Col-0 plants against E. carotovora subsp. carotovora. This is in agreement with previous work with E. amylovora and $P$. syringae pv. syringae harpins, which have been shown to induce SAR in Arabidopsis (Dong et al. 1999) and in cucumber (Strobel et al. 1996), respectively. Our results show that the HrpN-induced resistance depends on both SA and JA signaling. Bacterial growth was not arrested in SAdeficient NahG plants, indicating that induction of resistance is dependent on salicylic acid. This dependence is expected, since the harpin-induced resistance is believed to be a form of SAR characterized by $P R$ gene induction. Interestingly, the JA-insensitive coil, as well as jarl, plants showed no resistance development whatsoever and consistently, when the both signal pathways were blocked, as in the NahG coil plants, the bacteria grew to the highest density. This result is somewhat contradictory to the previously studied E. amylovora harpin-induced resistance (Dong et al. 1999). In this study, JA-insensitive jarl plants were used to show that $\mathrm{HrpN}$-induced resistance against $P$. syringae and $P$. parasitica is independent of jasmonic acid. However, we can conclude that the JA-dependent signal pathway contributes to the $\mathrm{HrpN}$-induced resistance against $E$. carotovora subsp. carotovora. This is further supported by the results showing the requirement for both SA- and JA-dependent signal pathways in $\mathrm{HrpN}$-induced expression of defense genes of Arabidopsis.

Our results demonstrate that E. carotovora subsp. carotovora strain SCC1 triggers both SA-dependent and JA/ETdependent defense pathways and that the level of SCC1induced PRI and PDF1.2 gene expression is higher than with either of the E. carotovora subsp. carotovora elicitors HrpN or PehA alone. Accordingly, these elicitors seem to cooperate when applied together, and the induced plant response is amplified due to their synergistic action. Simultaneous activation of both SA-dependent and JA- and ET-dependent signaling pathways accelerated and enhanced $P R I$ and $P D F 1.2$ expression, both locally and systemically. Especially conspicuous was the strong systemic induction of $P R l$, which increased above the level of local induction. Also, the production of ROS and ion leakage were enhanced, leading to a more rapid and massive cell death. Chandra and associates (2000) have observed similar synergism with cell-suspension cultures of soybean, in which the simultaneous application of different elicitors amplified the following oxidative burst. Although we have no data of the physiological levels of either HrpN or PehA during the actual interaction between the plant and the pathogen, it is tempting to speculate that the strong plant responses caused by SCC1 are, indeed, due to synergism of these two elicitors.

Unlike the situation in ISR, the JA/ET-dependent defense triggered by E. carotovora is not mediated by NPR1 (NormanSetterblad et al. 2000), the key regulator in SAR. Since the two signal pathways triggered by Erwinia-derived elicitors are not interconnected at NPR1, the question arises as to how this synergistic effect is achieved. Most of the phytopathogens seem to predominantly activate either SA- or JA/ETdependent defense mechanisms in plants (Thomma et al. 1998, 2001b). In contrast, E. carotovora subsp. carotovora SCC1 is a peculiar and interesting example of a pathogen that appears to trigger plant responses dependent on both SA and JA/ET signaling. One possibility is that a signal molecule or second messenger common to both pathways is produced which, in turn, may amplify the pathway-specific signals. We have studied the enhanced state of response by using transgenic NahG plants and various signal pathway mutants. Our results suggest that this amplification is somewhat more dependent on SA than on JA and ET. Treatment of plants with both HrpN and PehA did not result in stronger induction of PDF1.2 in $n p r l$ and NahG plants. In contrast, $P R l$ was still more strongly induced in coil, triple-fad, and jarl, as well as in ein2-1 mutants, compared with the induction by HrpN only (data not shown). As expected, there was no or very little accumulation of $P D F 1.2$ in JA/ET-signaling mutants ein2-1, coil, and triple-fad or PR1 in SA-deficient NahG plants and SA-signaling mutant $n p r l$. In the JA-insen-

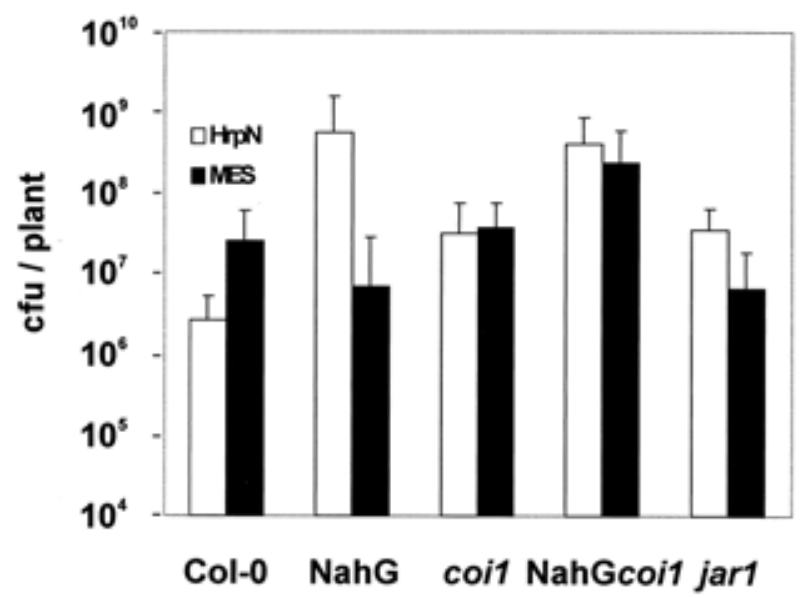

Fig. 4. Contribution of salicylic acid- or jasmonate-dependent defense pathways in HrpN-induced resistance against Erwinia carotovora subsp. carotovora SCC1. Two leaves of Arabidopsis plants were inoculated by infiltration with $\left(3 \times 10^{6}\right.$ to $6 \times 10^{6} \mathrm{CFU} /$ plant $)$ E. carotovora subsp. carotovora SCC1 $24 \mathrm{~h}$ after pretreatment of two opposite leaves with $\mathrm{HrpN}(300 \mu \mathrm{g} / \mathrm{ml})$ (white bars) or $5 \mathrm{mM}$ MES buffer (black bars). Growth of bacteria in Col-0 as well as in transgenic NahG and in the mutants coil, jarl, and NahG coil was measured $24 \mathrm{~h}$ after inoculation from five to seven parallel samples by plating serial dilutions on L-Amp $\left(50 \mu \mathrm{g} \mathrm{ml}^{-1}\right)$ plates. Bacterial growth is indicated as CFU/plant \pm standard error. 
sitive mutant jarl, the expression of PDF1.2 is only reduced, suggesting that the jarl allele is somewhat leaky. The amplification of defense gene expression in systemic tissues was even more profound, which was especially evident in the induction of $P R 1$. This effect could also be achieved by first activating either of the signaling pathways independently with their cognate elicitors (data not shown).

The massive, rapidly appearing, HR-like lesions triggered by simultaneous addition of elicitors HrpN and PehA are accompanied by enhanced ion leakage and increased production of superoxide in the margins of lesions, indicating accelerated cell death. Why would such a potent pathogen as $E$. carotovora subsp. carotovora use an arsenal of virulence determinants to trigger multiple responses including cell death in the host? One possibility is that host responses, such as oxidative burst and cell death, could be utilized by the pathogen to facilitate infection. The enhanced plant responses could lead to ROS levels deleterious to the plant, and the dying plant cells could serve as a source of nutrients to the growing bacterial population. Although pathogeninduced PCD is normally associated with HR and disease resistance, there is accumulating evidence to also support the role of PCD in compatible interactions (Govrin and Levine 2000; Stone et al. 2000). Govrin and Levine showed that the HR triggered by the necrotrophic fungal pathogen Botrytis cinerea actually facilitates pathogenesis. Similarly, it would also be possible that the pathogenesis of a necrotroph like $E$. carotovora could be promoted by local plant responses such as oxidative burst and cell death triggered by the synergistic action of pathogen elicitors. However, this needs to be confirmed through further experiments, and indeed, current studies are directed to elucidate the contribution of PCD to pathogenesis of E. carotovora.

\section{MATERIALS AND METHODS}

\section{Plant material and growth conditions.}

Arabidopsis thaliana plants used in all experiments were derived from ecotype Colombia (Col-0). Seeds of transgenic NahG plants (Delaney et al. 1995) were provided by J. Ryals (Ciba Geigy, Research Triangle Park, NC, U.S.A.), seeds of the fatty acid desaturase triple fad (fad3-2/fad7-2/fad8) mutant by J. Browse (Washington State University, Pullman, U.S.A.), and seeds of JA-insensitive coil-1 (Feys et al. 1994) by J. Turner (University of East Anglia, Norwich, U.K.). Seeds of ethylene response mutant ein2-1 (Guzmán and Ecker 1990), JA response mutant jarl-1 (Staswick and Howell 1992), and the nonexpresser of PR genes nprl-1 (Cao et al. 1994) were obtained from the Biological Resource Center (accession numbers CS3071, CS8072 and CS3726; Columbus, OH, U.S.A.). The Arabidopsis NahG coil plants were generated using pollen from kanamycin-resistant NahG plants to fertilize homozygous male-sterile coil plants. The $\mathrm{F}_{2}$ progeny were germinated on Murashige and Skoog (MS) plates (Murashige and Skoog 1962) containing $100 \mu \mathrm{g}$ of kanamycin per $\mathrm{ml}$ for 5 days to screen for kanamycin resistance, followed by screening for insensitivity to MeJA on MS plates containing $20 \mu \mathrm{M}$ MeJA for the next 5 days. Homozygous plants were backcrossed with pollen from $\mathrm{NahG}$ plants, and the $\mathrm{F}_{4}$ progenies were screened for homozygous NahG lines and maintained as coil/Coil hemizygous plants. All plants were grown in $1: 1$ vermiculite and peat mixture with a 12 -h light period at $22^{\circ} \mathrm{C}$, and three- to four-week-old plants were used for experiments. Tobacco (Nicotiana tabacum cv. SR1) was grown at $24^{\circ} \mathrm{C}$ with a 16 -h light period in vermiculite provided with fertilizer weekly. Sixweek-old plants were used for experiments.

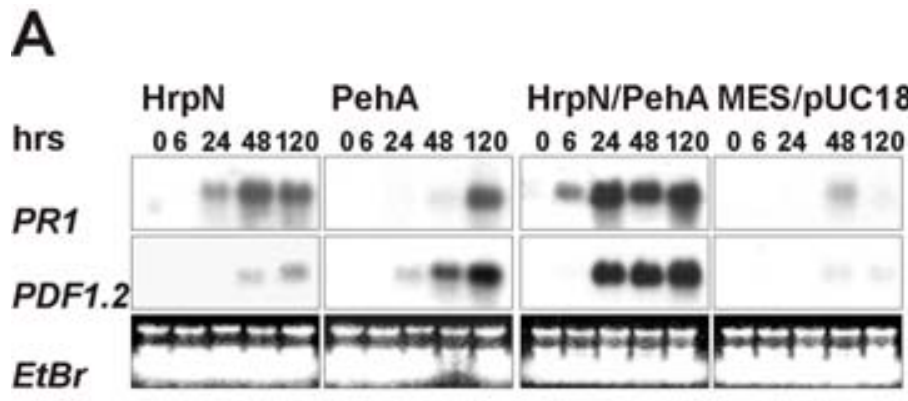

B

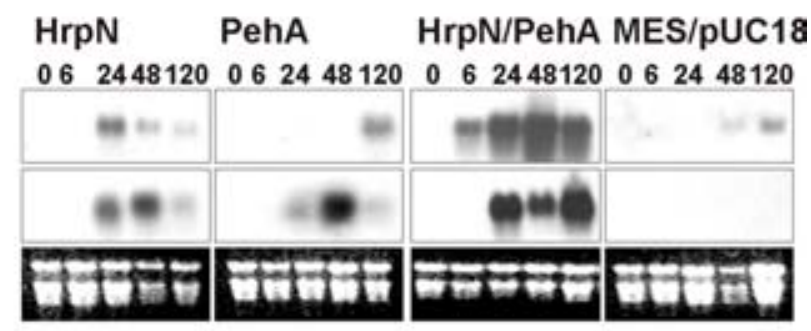

C

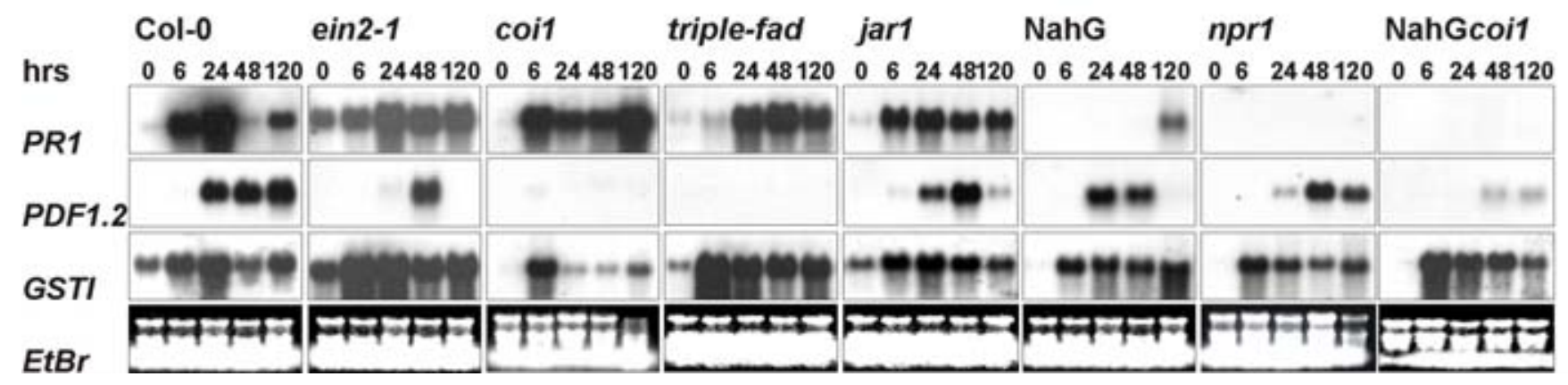

Fig. 5. Enhancement of plant response by simultaneous activation of salicylic acid and jasmonate/ethylene defense pathways with HrpN and PehA. Arabidopsis Col-0 plant leaves were treated simultaneously with HrpN (300 $\mu \mathrm{g} / \mathrm{ml})$ and PehA (6.2 units/ml) or with the corresponding controls. A, Local (treated) and B, systemic (untreated) samples were collected. C, Local samples were collected from Arabidopsis wild-type Col-0, transgenic NahG, and mutants coil, triple-fad, jarl, ein2-1, and NahG coil after the leaves were treated simultaneously with HrpN and PehA. In all experiments, the leaf samples were collected $0,6,24,48$, and $120 \mathrm{~h}$ after the treatment. Total RNA was extracted and analyzed by Northern hybridization with gene-specific probes for PR1, PDF1.2, and GSTI. As a control for equal loading, ethidium bromide staining of RNA is shown at the bottom. 
Bacterial strains, plasmids, and media.

E. carotovora subsp. carotovora strain SCC1 (Rantakari et al. 2001) was propagated in L-medium (Miller 1972) at $28^{\circ} \mathrm{C}$ and Escherichia coli strains HB101 (Boyer and RoullandDussoix 1969), JM109 (Yanisch-Perron et al. 1985) and M15 (pREP4) (Qiagen $\mathrm{GmbH}$, Hilden, Germany) at $37^{\circ} \mathrm{C}$. Ampicillin was added to a final concentration of 100 or $150 \mu \mathrm{g} \mathrm{ml}^{-1}$ and kanamycin to $25 \mu \mathrm{g} \mathrm{ml}{ }^{-1}$, when required.

\section{Elicitor preparations and treatments.}

The coding region of $h r p N$ was amplified by PCR using primers 5'-TATTGGATCCCTTAATTCTCTTGG-3' and 5'TAATAAGCTTTAGCTGGAGAGC-3', using pTPE100, pBluescript $\mathrm{SK}^{-}$containing the $h r p N$ gene from $E$. carotovora subsp. carotovora SCC1 as template. The resulting 1,000-bp product was purified and cloned to the BamHI site of the pQE30 expression vector (Qiagen $\mathrm{GmbH}$ ) to produce pTPE101. Sequencing of pTPE101 was performed by an automatic laser fluorescent sequencer (Pharmacia, Uppsala, Sweden). pTPE101 was transformed to Escherichia coli M15 cells in order to express HrpN. Expression of the protein was analyzed in SDSPAGE in $10 \%$ polyacrylamide gel. Immunoblotting was performed as described by Sambrook and associates (1989) using penta-his antibody (Qiagen $\mathrm{GmbH}$ ) in a 1:7,500 dilution. In order to purify the HrpN protein, a 100-ml culture of Escherichia coli strain M15 bacteria containing pTPE101 was propagated on a rotary shaker at $37^{\circ} \mathrm{C}$. When the optical density at $600 \mathrm{~nm}\left(\mathrm{OD}_{600}\right)$ reached 0.8 the expression of the HrpN gene was induced by adding $1 \mathrm{mM}$ IPTG (isopropyl- $\beta$-D-thiogalactopyranoside). After additional growth for $2 \mathrm{~h}$, the cells were collected by centrifugation $\left(5,000 \times g\right.$ for $30 \mathrm{~min}$ at $\left.4^{\circ} \mathrm{C}\right)$. The extraction and elution of N-terminally his ${ }_{6}$-tagged $\mathrm{HrpN}$ was done according to the manufacturer's instructions (Qiagen $\mathrm{GmbH})$. After the elution, urea was removed by dialyzing against $5 \mathrm{mM}$ MES (2-[N-Morpholino] ethanesulfonic acid) for $24 \mathrm{~h}$ at $4^{\circ} \mathrm{C}$. Removal of urea was confirmed with thin layer chromatography. Sterile filtered $5 \mathrm{mM}$ MES was used as a control for HrpN. PehA preparation was done according to Palomäki and Saarilahti (1997). The activity of the preparation used in the experiments was 6.2 units per ml. A preparation of pUC18 plasmid was made similarly and used as a control for PehA. The HrpN preparation and the MES control were applied to plants by infiltration with a 2-ml needleless syringe. PehA and pUC18-control were pipetted as $5 \times 2.5$ - $\mu$ l droplets on leaves. Infection with SCC1 was done by infiltrating bacterial suspension containing approximately $3 \times 10^{6}$ to $5 \times 10^{6}$ CFU per ml with $0.9 \% \mathrm{NaCl}$ as a control. All the treatments were carried out in a growth chamber with a 12-h light period at $22^{\circ} \mathrm{C}, 70 \%$ humidity, and photon flux density of 200 to 220 $\mu \mathrm{mol} \mathrm{m} \mathrm{m}^{-2}$.

\section{Inoculation of plants and evaluation of infection.}

For evaluation of bacterial growth in planta, three- to fourweek-old plants were infected with $3 \times 10^{6}$ to $5 \times 10^{6} \mathrm{CFU}$ per $\mathrm{ml}$ of E. carotovora subsp. carotovora $\mathrm{SCC} 1$. An overnight culture was centrifuged for $15 \mathrm{~min}(4,000 \times g)$, and the pellet was resuspended in $1 \mathrm{ml} 0.9 \% \mathrm{NaCl}$ and was diluted to the appropriate concentration. After infiltration with a needleless syringe, the plants were kept at photon flux density of 100 to $120 \mu \mathrm{mol} \mathrm{m} \mathrm{mec}^{-1}$ at more than $90 \%$ humidity to facilitate infection. The bacterial growth was determined by homogenizing the infected plants in $20 \mathrm{ml} 0.9 \% \mathrm{NaCl}$ and plating serial dilutions on L-plates containing ampicillin at $50 \mu \mathrm{g} \mathrm{ml}^{-1}$.

\section{RNA blot analyses.}

Total RNA from plant leaves was prepared by $\mathrm{SDS} /$ phenol/chloroform extraction and $\mathrm{LiCl}$ precipitation
(Kingston 1997). RNA was separated by electrophoresis on denaturing formaldehyde agarose gel for size fractionation and then transferred onto positively charged nylon membranes (Boehringer Mannheim, Mannheim, Germany) via capillary transfer (Sambrook et al. 1989). The amount of RNA used per lane was $5 \mu \mathrm{g}$. Membranes were hybridized with PCR-labeled gene-specific digoxigenin (DIG) probes. DNA probes were amplified from the cDNA of $P R-1$ (Uknes et al. 1992). PDF1.2 and GST1 probes were obtained from the Arabidopsis Biological Resource Center (GenBank accession numbers T04323 and N37195). All hybridizations were performed with Dig-Easy $\mathrm{Hyb}$ buffer (Boehringer Mannheim) at $50^{\circ} \mathrm{C}$. Membranes were washed twice in $2 \times \mathrm{SSC}(1 \times \mathrm{SSC}$ is $0.15 \mathrm{M} \mathrm{NaCl}$ plus 0.015
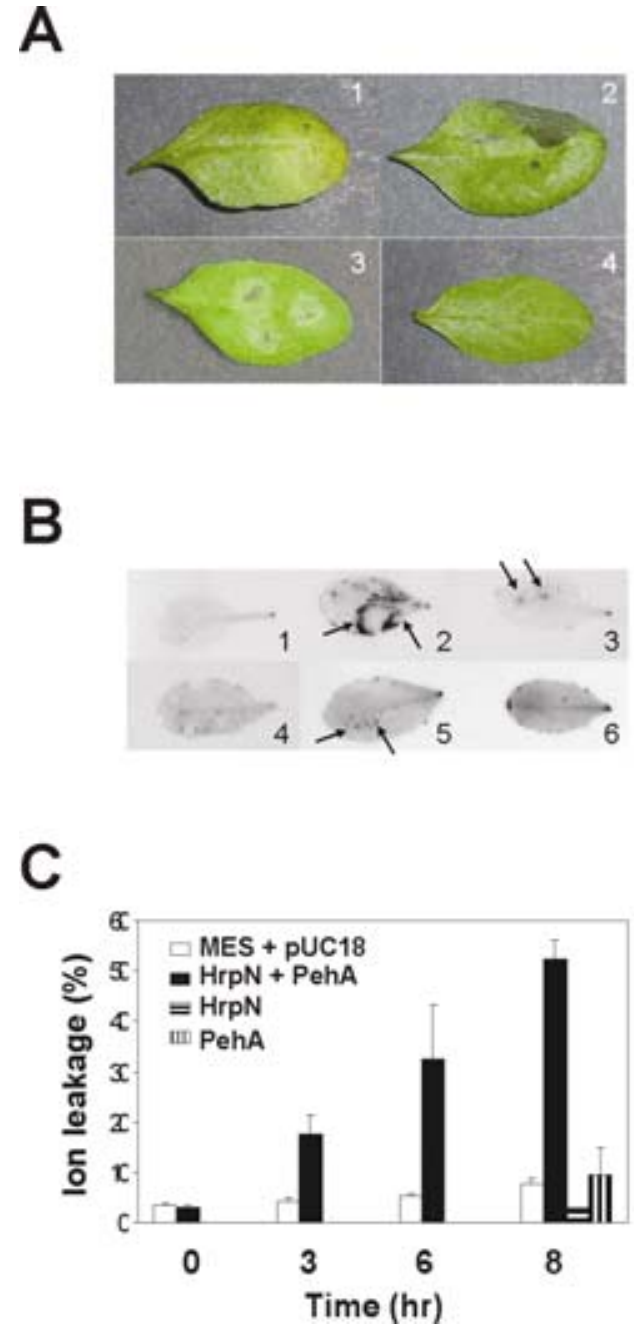

Fig. 6. Simultaneous treatment with $\mathrm{HrpN}$ and PehA triggers accelerated lesion formation and cell death in Arabidopsis. Arabidopsis leaves were treated simultaneously with $\mathrm{HrpN}(300 \mu \mathrm{g} / \mathrm{ml})$ and PehA (6.2 units/ml). Control leaves were treated in the same way with $5 \mathrm{mM}$ MES buffer and a pUC18 preparation. A, Visible symptoms on representative Arabidopsis leaves $24 \mathrm{~h}$ after treatment with HrpN only (1), HrpN + PehA (2), PehA only (3), or MES + pUC18 (4). B, Superoxide accumulation in treated plants. Untreated leaves (1) and leaves $2 \mathrm{~h}$ after application of $\mathrm{HrpN}+$ PehA (2, 3), HrpN only (4), PehA only (5), or MES + pUC18 (6) were detached and were infiltrated with nitroblue tetrazolium (NBT). The presence of the dark formazan precipitate indicates the location of superoxide. The specificity of the NBT staining was verified by coinfiltration of HrpN + PehA treated leaves (3) with NBT and superoxide dismutase. Arrows indicate where PehA was applied. C, Cell death was measured as relative ion leakage (percentage of total ions \pm standard error) at the indicated time points after treatment with MES + pUC18 (white bars), HrpN + PehA (black bars), HrpN only (bars with horizontal stripes), or PehA only (bars with vertical stripes). 
M sodium citrate), $0.1 \%$ (wt/vol) SDS at room temperature for $10 \mathrm{~min}$ and twice in $0.1 \times \mathrm{SSC}, 0.1 \%$ (wt/vol) SDS at $50^{\circ} \mathrm{C}$ for $15 \mathrm{~min}$. Immunodetection was done with an alkaline phosphatase-conjugated antidigoxigenin antibody and was visualized with the chemiluminescent substrate CSPD according to the instructions of the manufacturer (Boehringer Mannheim).

\section{Ion leakage and superoxide staining.}

Cell death was measured by relative ion leakage (percentage of total ions plus or minus standard error) from leaves of Arabidopsis plants in $5 \mathrm{ml}$ of 18 Mohm water shaken for $1 \mathrm{~h}$. Measurements were carried out with a Mettler conductivity meter (Mettler Toledo GmbH, Greifensee, Switzerland). For detection of superoxides, Arabidopsis leaves were vacuum infiltrated with $10 \mathrm{mM} \mathrm{NaN}_{3}$ (in $10 \mathrm{mM} \mathrm{K}_{2} \mathrm{PO}_{4}, \mathrm{pH}$ 7.8) and were stained in the same buffer solution containing $0.1 \%$ NBT (Boehringer Mannheim). SOD (Roche Diagnostics, Mannheim, Germany) was used at a concentration of $0.5 \mathrm{mg}$ per $\mathrm{ml}$, when needed. After $40 \mathrm{~min}$, the leaves were cleared by boiling in alcohol and lactophenol (2:1) for $5 \mathrm{~min}$ and were rinsed twice with 50\% ethanol (Jabs et al. 1996).

\section{ACKNOWLEDGMENTS}

We thank H. Mikkonen and J. Kallio for excellent technical assistance. We thank J. Turner for coil-1 mutant seeds, J. Ryals for transgenic Arabidopsis NahG seeds, and J. Browse for the fatty acid desaturase triple fad seeds. This study was supported by the Academy of Finland (projects 38033, 42180, 49905, 44252, and 44883; Finnish Centre of Excellence Programme 2000-2005), Biocentrum Helsinki, and the Viikki Graduate School of Biosciences.

\section{LITERATURE CITED}

Barny, M. A. 1995. Erwinia amylovora hrpN mutants, blocked in harpin synthesis, express a reduced virulence on host plants and elicit variable hypersensitive reactions on tobacco. Eur. J. Plant Pathol. 101:333340.

Bauer, D. W., Wei, Z.-M., Beer, S. V., and Collmer, A. 1995. Erwinia chrysanthemi harpin ${ }_{\mathrm{Ech}}$ : An elicitor of the hypersensitive response that contributes to soft-rot pathogenesis. Mol. Plant-Microbe Interact. 8:484-491.

Bauer, D. W., Zumoff, C. H., Theisen, T. M., Bogdanove, A. J., and Beer, S. V. 1997. Optimized production of Erwinia amylovora harpin and its use to control plant disease and enhance plant growth. Phytopathology 87:7.

Boller, T. 1995. Chemoperception of microbial signals in plant cells. Annu. Rev. Physiol. Plant Mol. Biol. 46:189-214.

Boyer, H. W., and Roulland-Dussoix, D. 1969. A complementation analysis of the restriction and modification of DNA in Escherichia coli. J. Mol. Biol. 41:459-472.

Brader, G., Tas, É., and Palva, E. T. 2001. Jasmonate-dependent induction of indole glucosinolates in Arabidopsis by culture filtrates of the nonspecific pathogen Erwinia carotovora. Plant Physiol. 126:849-860.

Cao, H., Bowling, S. A., Gordon, A. S., and Dong, X. 1994. Characterization of an Arabidopsis mutant that is non-responsive to inducers of systemic acquired resistance. Plant Cell 6:1583-1592.

Chandra, S., Cessna, S. G., Yahraus, T., Devine, R., and Low, P. S. 2000 Homologous and heterologous desensitization and synergy in pathways leading to the soybean oxidative burst. Planta 211:736-742.

Conklin, P. L., and Last, R. L. 1995. Differential accumulation of antioxidant mRNAs in Arabidopsis thaliana exposed to ozone. Plant Physiol. 109:203-212.

Cui, Y., Madi, L., Mukherjee, A., Dumenyo, C. K., and Chatterjee, A. K. 1996. The RsmA- mutants of Erwinia carotovora subsp. carotovora strain Ecc71 overexpress $h r p N_{\mathrm{Ecc}}$ and elicit a hypersensitive reactionlike response in tobacco leaves. Mol. Plant-Microbe Interact. 9:565573.

Dangl, J. L., Dietrich, R. A., and Richberg, M. H. 1996. Death don't have no mercy: Cell death programs in plant-microbe interactions. Plant Cell 8:1793-1807.

Delaney, T. P., Friedrich, L., and Ryals, J. A. 1995. Arabidopsis signal transduction mutant defective in chemically and biologically induced disease resistance. Proc. Natl. Acad. Sci. U.S.A. 92:6602-6606.

Desikan, R., Hancock, J. T., Ichimura, K., Shinozaki, K., and Neill, S. J.
2001. Harpin induces activation of the Arabidopsis mitogen-activated protein kinases AtMPK4 and AtMPK6. Plant Physiol. 126:1579-1587.

Doares, S. H., Narváez-Vásquez, J., Conconi, A., and Ryan, C. A. 1995. Salicylic acid inhibits synthesis of proteinase inhibitors in tomato leaves induced by systemin and jasmonic acid. Plant Physiol. 108:1741-1746.

Dong, H., Delaney, T. P., Bauer, D. W., and Beer, S. V. 1999. Harpin induces disease resistance in Arabidopsis through the systemic acquired resistance pathway mediated by salicylic acid and the NIMI gene. Plant J. 20:207-215.

Feys, B. J. F., Benedetti, C. E., Penfold, C. N., and Turner, J. G. 1994. Arabidopsis mutants selected for resistance to the phytotoxin coronatine are male sterile, insensitive to methyl jasmonate, and resistant to a bacterial pathogen. Plant Cell 6:751-759.

Flor, H. H. 1971. Current status of the gene-for-gene concept. Annu. Rev. Phytopathol. 9:275-296.

Frederick, R. D., Ahmad, M., Majerczak, D. R., Arroyo-Rodríguez, A. S., Manulis, S., and Coplin, D. L. 2001. Genetic organization of the Pantoea stewartii subsp. stewartii hrp gene cluster and sequence analysis of the $h r p A, h r p C, h r p N$, and wtsE operons. Mol. Plant-Microbe Interact. 14:1213-1222.

Glazebrook, J. 1999. Genes controlling expression of defense responses in Arabidopsis. Curr. Op. Plant Biol. 2:280-286.

Goodman, R. M., and Novacky, A. J. 1994. The Hypersensitive Reaction in Plants to Pathogens: A Resistance Phenomenon. American Phytopathological Society Press, St. Paul, MN, U.S.A.

Govrin, E. M., and Levine, A. 2000. The hypersensitive response facilitates plant infection by the necrotrophic pathogen Botrytis cinerea. Curr. Biol. 10:751-757.

Greenberg, J. T. 1997. Programmed cell death in plant-pathogen interactions. Annu. Rev. Plant Phys. Mol. Biol. 48:525-545.

Gupta, V., Willits, M. G., and Glazebrook, J. 2000. Arabidopsis thaliana EDS4 contributes to salicylic acid (SA)-dependent expression of defense responses: Evidence for inhibition of jasmonic acid signaling by SA. Mol. Plant-Microbe Interact. 13:503-511.

Guzmán, P., and Ecker, J. R. 1990. Exploiting the triple response of Arabidopsis to identify ethylene-related mutants. Plant Cell 2:513-523.

He, S. Y., Huang, H.-C., and Collmer, A. 1993. Pseudomonas syringae pv. syringae harpin ${ }_{\mathrm{Pss}}$ : A protein that is secreted via the hrp pathway and elicits the hypersensitive response in plants. Cell 73:1255-1266.

Huang, H. C., Schuurink., R., Denny, T. P., Atkinson, M. M., Baker, C. J., Yucel, I., Hutcheson, S. W., and Collmer, A. 1988. Molecular cloning of a Pseudomonas syringae pv. syringae gene cluster that enables Pseudomonas fluorescens to elicit the hypersensitive response in tobacco plants. J. Bacteriol. 170:4748-4756.

Jabs, T., Dietrich, R. A., and Dangl, J. L. 1996. Initiation of runaway cell death in an Arabidopsis mutant by extracellular superoxide. Science 273:1853-1856.

Keen, N. T. 1990. Gene-for-gene complementarity in plant-pathogen interactions. Annu. Rev. Genet. 24:447-463.

Kingston, R. F. 1997. Precipitation and analysis of RNA. Pages 4.3.14.3.4 in: Current Protocols in Molecular Biology. Ausubel, F. M., Brent, R., Kingston, R. E., Moore, D. D., Seidman, J. G., Smith, J. A., and Struhl, K., eds. John Wiley and Sons, New York.

Kotoujansky, A. 1987. Molecular genetics of pathogenesis by soft-rot Erwinias. Annu. Rev. Phytopathol. 25:405-430.

Lawton, K. A., Potter, S. L., Uknes, S., and Ryals, J. 1994. Acquired resistance signal transduction in Arabidopsis is ethylene independent. Plant Cell 6:581-588.

Miller, J. H. 1972. Experiments in Molecular Genetics. Cold Spring Harbor Laboratory Press, Cold Spring Harbor, NY, U.S.A.

Mukherjee, A., Cui, Y., Liu, Y., and Chatterjee, A. K. 1997. Molecular characterization and expression of the Erwinia carotovora $h r p N_{\mathrm{Ecc}}$ gene, which encodes an elicitor of the hypersensitive reaction. Mol. Plant-Microbe Interact. 10:462-471.

Murashige T., and Skoog, F. 1962. A revised medium for rapid growth and bioassays with tobacco tissue cultures. Physiol. Plant 15:473-479.

Niki, T., Mitsuhara, I., Seo, S., Ohtsubo, N., and Ohashi, Y. 1998. Antagonistic effect of salicylic acid and jasmonic acid on the expression of pathogenesis-related (PR) protein genes in wounded mature tobacco leaves. Plant Cell Phys. 39:500-507.

Norman-Setterblad, C., Vidal, S., and Palva, E. T. 2000. Interacting signal pathways control defense gene expression in Arabidopsis in response to cell wall-degrading enzymes from Erwinia carotovora. Mol. PlantMicrobe Interact. 13:430-438.

Nürnberger, T. 1999. Signal perception in plant pathogen defense. Cell. Mol. Life Sci. 55:167-182.

Palomäki, T., and Saarilahti, H. T. 1997. Isolation and characterization of new C-terminal substitution mutations affecting secretion of polygalacturonase in Erwinia carotovora ssp. carotovora. FEBS (Fed. Eur. 
Biochem. Soc.) Lett. 400:122-126.

Palva, T. K., Holmström, K.-O., Heino, P., and Palva, E. T. 1993. Induction of plant defense response by exoenzymes of Erwinia carotovora subsp. carotovora. Mol. Plant-Microbe Interact. 6:190-196.

Peña-Cortés, H., Albrecht, T., Prat, S., Weiler, E. W., and Willmitzer, L. 1993. Aspirin prevents wound-induced gene expression in tomato leaves by blocking jasmonic acid biosynthesis. Planta 191:123-128.

Penninckx, I. A. M. A., Eggermont, K., Terras, F. R. G., Thomma, B. P. H. J., Samblanx, G. W. D., Buchala, A., Métraux, J.-P., Manners, J. M. and Broekaert, W. F. 1996. Pathogen-induced systemic activation of a plant defensin gene in Arabidopsis follows a salicylic acid-independent pathway. Plant Cell 8:2309-2323.

Penninckx, I. A. M. A., Thomma, B. P. H. J., Buchala, A., Métraux, J.-P. and Broekaert, W. F. 1998. Concomitant activation of jasmonate and ethylene response pathways is required for induction of a plant defensin gene in Arabidopsis. Plant Cell 10:2103-2113.

Pérombelon, M. C. M., and Kelman, A. 1980. Ecology of the soft rot Erwinias. Annu. Rev. Phytopathol. 18:361-387.

Petersen, M., Brodersen, P., Naested, H., Andreasson, E., Lindhart, U., Johansen, B., Nielsen, H. B., Lacy, M., Austin, M. J., Parker, J. E., Sharma, S. B., Klessig, D. F., Martienssen, R., Mattsson, O., Jensen, A. B., and Mundy, J. 2000. Arabidopsis MAP kinase 4 negatively regulates systemic acquired resistance. Cell 103:1111-1120.

Pieterse, C. M., van Wees, S. C. M., van Pelt, J. A., Knoester, M., Laan, R., Gerrits, H., Weisbeek, P. J., and van Loon, L. C. 1998. A novel signaling pathway controlling induced systemic resistance in Arabidopsis. Plant Cell 10:1571-1580.

Pieterse, C. M. ., and van Loon, L. C. 1999. Salicylic acid-independent plant defense pathways. Trends Plant Sci. 4:52-58

Rantakari, A., Virtaharju, O., Vähämiko, S., Taira, S., Palva, E. T., Saarilahti, H. T., and Romantschuk, M. 2001. Type III secretion contributes to the pathogenesis of the soft-rot pathogen Erwinia carotovora: Partial characterization of the hrp gene cluster. Mol. Plant-Microbe Interact. 14:962-968.

Reymond, P., and Farmer, E. E. 1998. Jasmonate and salicylate as globa signals for defense gene expression. Curr. Op. Plant Biol. 1:404-411.

Ryals, J. A., Neuenschwander, U. H., Willits, M. G., Molina, A., Steiner, H.-Y., and Hunt, M. D. 1996. Systemic acquired resistance. Plant Cell 8:1809-1819.

Sambrook, J., Fritsch, E. F., and Maniatis, T. 1989. Molecular Cloning: A Laboratory Manual. 2nd ed. Cold Spring Harbor Laboratory Press. Cold Spring Harbor, NY, U.S.A.

Staswick, P. E., and Howell, S. H. 1992. Methyl jasmonate inhibition of root growth and induction of a leaf protein are decreased in an Arabidopsis thaliana mutant. Proc. Natl. Acad. Sci. U.S.A. 89:6837-6840.

Sticher, L., Mauch-Mani, B., and Metraux, J. P. 1997. Systemic acquired resistance. Annu. Rev. Phytopathol. 35:235-270.

Stone, J. M., Heard, J. E., Asai, T., and Ausubel, F. M. 2000. Simulation of fungal-mediated cell death by fumnisin B1 and selection of fumnisin B1-resistant (fbr) Arabidopsis mutants. Plant Cell 12:1811-1822.

Strobel, N. E., Ji, C., Gopalan, S., Kuc, J. A., and He, S. Y. 1996. Induction of systemic acquired resistance in cucumber by Pseudomonas syringae pv. syringae $61 \mathrm{HrpZ}_{\mathrm{Pss}}$ protein. Plant J. 9:431-439.

Thomma, B. P. H. J., Eggermont, K., Penninckx, I. A. M. A., MauchMani, B., Vogelsang, R., Cammue, B. P. A., and Broekaert, W. F. 1998. Separate jasmonate-dependent and salicylate-dependent defenseresponse pathways in Arabidopsis are essential for resistance to distinct microbial pathogens. Proc. Natl. Acad. Sci. U.S.A. 95:1510715111.

Thomma, B. P. H. J., Penninckx, I. A. M. A., Broekaert, W. F., and Cammue, B. P. A. 2001a. The complexity of disease signaling in Arabidopsis. Curr. Opin. Immunol. 13:63-68.

Thomma, B. P. H. J., Tierens, K. F. M., Penninckx, I. A. M. A., MauchMani, B., Broekaert, W. F., and Cammue, B. P. A. 2001b. Different micro-organisms differentially induce Arabidopsis disease response pathways. Plant Phys. Biochem. 39:673-680.

Uknes, S., Mauch-Mani, B., Moyer, M., Potter, S., Williams, S., Dincher, S., Chandler, D., Slusarenko, A., Ward, E., and Ryals, J. 1992. Acquired resistance in Arabidopsis. Plant Cell 4:645-656.

van Loon, L. C., Bakker, P. A. H. M., and Pieterse, C. M. J. 1998 Systemic resistance induced by rhizosphere bacteria. Annu. Rev. Phytopathol. 36:453-483.

Vidal, S., Ponce, D.-L, I., Denecke, J., and Palva, E. T. 1997. Salicylic acid and the plant pathogen Erwinia carotovora induce defense genes via antagonistic pathways. Plant J. 11:115-123.

Vidal, S., Eriksson, A. R. B., Montesano, M., Denecke, J., and Palva, E. T. 1998. Cell wall-degrading enzymes from Erwinia carotovora cooperate in the salicylic acid-independent induction of a plant defense response. Mol. Plant-Microbe Interact. 11:23-32.

Ward, E. R., Uknes, S. J., Williams, S. C., Dincher, S. S., Wiederhold, D. L., Alexander, D. C., Ahl-Goy, P., Métraux, J.-P., and Ryals, J. A. 1991. Coordinate gene activity in response to agents that induce systemic acquired resistance. Plant Cell 3:1085-1094.

Wei, Z.-M., Laby, R. J., Zumoff, C. H., Bauer, D. W., He, S. Y., Collmer, A., and Beer, S. V. 1992. Harpin, elicitor of the hypersensitive response produced by the plant pathogen Erwinia amylovora. Science 257:85-88.

Wei, Z.-M., and Beer, S. V. 1996. Harpin from Erwinia amylovora induces plant resistance. Acta Hortic. 411:223-225.

Xu, Y., Chang, P.-F. L., Liu, D., Narasimhan, M. L., Raghothama, K. G., Hasegawa, P. M., and Bressan, R. A. 1994. Plant defense genes are synergistically induced by ethylene and methyl jasmonate. Plant Cell 6:1077-1085.

Yanisch-Perron, C., Vieira, J., and Messing, J. 1985. Improved M13 phage cloning vectors and host strains: Nucleotide sequences of the M13mp18 and pUC19 vectors. Gene 33:102-119. 